\section{(Collectíne @nluestigation}

INTO

\section{THE AFTER-HISTORY OF GASTRO- ENTEROSTOMY. Report by}

ARTHUR P. LUFF, C.B.F., M.D., B.Sc., F.R.C.P., CONSULTING PHYSICIAN TO ST. MARY'S HOSPITAL; HONORARY DIRECTOR OF TME RESEARCH.

THE results of the operation for duodenal ulcers have been published in Part I (British Medical Journal, December 7th, 1929); the results for pyloric ulcers have been published in Part II, and for perforated duodenal and pyloric ulcers in Part III (British Medical Journal, December 14th, 1529). The present report deals similarly with the gastric ulcers. There were 645 reports of the results of operations for gastric ulcer. They consisted of 538 cases of ordinary gastric ulceration, 65 cases of hour-glass constriction, and 42 cases of perforated gastric ulcers. As it is somewhat unusual to have the records of 65 cases of hour-glass constriction it was considered advisable to prepare a separate report on those cases, and also on the cases of perforation.

\section{Part IV.-Gastric ULCERS.}

The answers to the various questions in connexion with the 538 cases of ordinary gastric ulceration have been carefully collated, and the results are embodied in the following tables.

\section{TABLE I.-Sex Incidence.}

Number of cases

$\begin{array}{lllll}\cdots & \ldots & \ldots & \ldots & \ldots\end{array}$

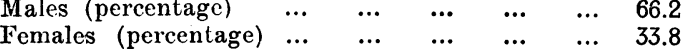

This table shows that twice as many cases occur among males as among females.

TABLe II.-Age Incidence (at T'ime of Operation).

\begin{tabular}{cccccccccc|c}
\hline Age. & \multicolumn{1}{c}{} & \multicolumn{1}{c}{ Percentage. } \\
\hline $19-30$ years & $\ldots$ & $\ldots$ & $\ldots$ & $\ldots$ & $\ldots$ & $\ldots$ & $\ldots$ & $\ldots$ & 9.0 \\
$30-40$ &. & $\ldots$ & $\ldots$ & $\ldots$ & $\ldots$ & $\ldots$ & $\ldots$ & $\ldots$ & $\ldots$ & 27.3 \\
$40-50$ &. & $\ldots$ & $\ldots$ & $\ldots$ & $\ldots$ & $\ldots$ & $\ldots$ & $\ldots$ & $\ldots$ & 38.0 \\
$50-60$ & $\ldots$ & $\ldots$ & $\ldots$ & $\ldots$ & $\ldots$ & $\ldots$ & $\ldots$ & $\ldots$ & $\ldots$ & 20.3 \\
$60-70$ &. & $\ldots$ & $\ldots$ & $\ldots$ & $\ldots$ & $\ldots$ & $\ldots$ & $\ldots$ & $\ldots$ & 5.4 \\
\hline
\end{tabular}

This table shoris that the najority of patients with gastric ulceration were operaical on between 20 and 50 years of age. Of the patients operated on between 19 and 30 years, two only were 19 years of age.

TABLE III.-Position or Site of Ulecr.

(Information on this point was given in 523 cases, including the hour-glass cases.)

\begin{tabular}{lccccc|c|c}
\hline \multicolumn{3}{c}{ Position cr Site. } & & & No. of Cases. & Percentage. \\
\cline { 1 - 5 } Lesser curvature & $\ldots$ & $\ldots$ & $\ldots$ & $\ldots$ & $\ldots$ & 377 & 72.2 \\
Near pylorus.. & $\ldots$ & $\ldots$ & $\ldots$ & $\ldots$ & $\ldots$ & 56 & 10.7 \\
Posterior wall & $\ldots$ & $\ldots$ & $\ldots$ & $\ldots$ & $\ldots$ & 55 & 10.5 \\
Anterior wall & $\ldots$ & $\ldots$ & $\ldots$ & $\ldots$ & $\ldots$ & 16 & 3.0 \\
Cardiac end $\ldots .$. & $\ldots$ & $\ldots$ & $\ldots$ & $\ldots$ & $\ldots$ & 14 & 2.6 \\
Greater curvature $\ldots$ & $\ldots$ & $\ldots$ & $\ldots$ & $\ldots$ & $\ldots$ & 5 & 1.0 \\
\hline
\end{tabular}

TABle IV.-Lilecr Adherent or. Non-adherent. (Information on these points was given in 167 cases, including the hour-glass cases.)

\begin{tabular}{|c|c|c|c|c|c|c|c|}
\hline . & & & & & & No. of Cases. & Percentage. \\
\hline Adherent $\quad .$. & $\ldots$ & $\ldots$ & $\ldots$ & $\ldots$ & $\ldots$ & 159 & 95.2 \\
\hline Non-adherent & $\ldots$ & $\ldots$ & $\ldots$ & $\ldots$ & $\ldots$ & 8 & 4.8 \\
\hline
\end{tabular}

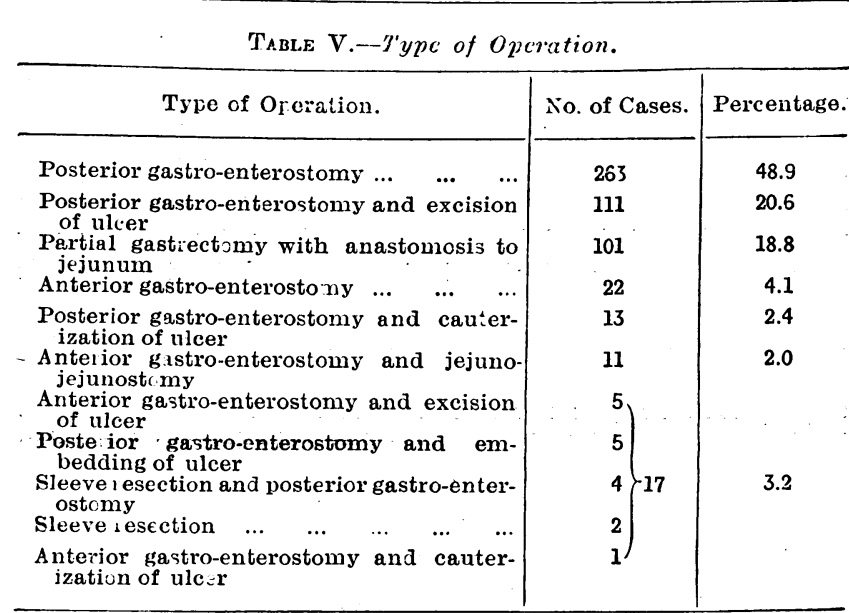

In addition, appendicectomy was performed in 9.8 per cent., and cholecystotomy in 0.7 per cent. of the cases. In some of the cases the reasons given for performing anterior gastro-enterostomy were that the stomach was either too fixed or that there was insufficient room for performing the posterior operation.

The reasons for operating wcre given in 417 cases. They are recorded in the following table.

TABLE VI.-Reasons for Operating.

\begin{tabular}{|c|c|c|c|c|c|c|c|c|}
\hline \multicolumn{6}{|c|}{ Symptoms. } & . & No. of Cases. & Percentage. \\
\hline Pain $\quad \ldots$ & $\cdots$ & $\cdots$ & $\cdots$ & $\bullet$ & $\ldots$ & $\ldots$ & 411 & 98.6 \\
\hline Vomiting & $\ldots$ & $\ldots$ & $\ldots$ & . & $\cdots$ & $\ldots$ & 285 & 68.3 \\
\hline Haematemes & & $\ldots$ & ... & ... & $\ldots$ & ... & 94 & 22.5 \\
\hline Haematen:es & sis a & $\mathrm{d} m$ & aena & ... & $\ldots$ & $\ldots$ & 9 & 2.0 \\
\hline Melaena & ... & $\ldots$ & $\ldots$ & $\ldots$ & $\ldots$ & $\ldots$ & 7 & 1.7 \\
\hline Loss of weigl & & $\ldots$ & $\ldots$ & ... & $\ldots$ &.. & 35 & 8.4 \\
\hline
\end{tabular}

Vomiting and haematemesis were both much more frequent in the gastric ulcer eases than in the duodenal and pyloric, but melaena was much moro frequent in the duodenal cases than in the gastric and pyloric.

'The direct results of operation in the 538 cases were as follows.

TABLE VII.-Rcsults of Opcration.

\begin{tabular}{|c|c|c|c|c|c|c|}
\hline \multicolumn{5}{|c|}{ Result. } & No. of Cases. & Percentage. \\
\hline Good recovery & $\ldots$ & $\ldots$ & ... & ... & 487 & 90.5 \\
\hline Delayed recovery & $\ldots$ & $\ldots$ & $\ldots$ & $\ldots$ & 3 & 0.6 \\
\hline Death ... ... & $\ldots$ & $\ldots$ & $\ldots$ & ... & 48 & 8.9 \\
\hline
\end{tabular}

The post-operative mortality is considerably higher than the 5.0 per cent. mortality among duodenal ulcers and the 2.6 per cent. mortality among pyloric ulcers.

The results in 299 cases submitted to $x$-ray examination prior to operation are shown in the following table.

\begin{tabular}{|c|c|c|c|c|c|c|c|c|}
\hline Result. & & & & & & & & Percentage. \\
\hline Positive ... & $\ldots$ & $\ldots$ & $\cdots$ & $\ldots$ & $\ldots$ & $\ldots$ & $\ldots$ & 54.9 \\
\hline Negative ... & $\ldots$ & $\ldots$ & $\ldots$ & $\ldots$ & $\ldots$ & $\ldots$ & $\ldots$ & 18.0 \\
\hline Delay in emptying & $\ldots$ & $\ldots$ & $\ldots$ & $\ldots$ & $\ldots$ & $\ldots$ & $\ldots$ & 27.1 \\
\hline
\end{tabular}

In 105 cases test meals were employed prior to operation. The results are shown in the following table.

TABL̇e IX.-Results of Test MI cals.

\begin{tabular}{|c|c|c|c|c|c|c|}
\hline $\mathbf{R} \in$ sult. & & & & & & Percentage. \\
\hline Hyperchlorhydria $\ldots$ & $\ldots$ & $\ldots$ & $\therefore$ & $\ldots$ & $\ldots$ & 40.0 \\
\hline Low acidity $\quad \ldots$ & $\ldots$ & $\ldots$ & $\ldots$ & $\ldots$ & $\ldots$ & 52.4 \\
\hline No free hyçrochloric acid & $\ldots$ & $\ldots$ & $\ldots$ & & $\ldots$ & 7.6 \\
\hline
\end{tabular}


After-Histories of the Operation Cases.

The 538 cases dealt with in Tables I, II, V, and VII include 392 cases in which the after-histories were given, 26 cases in which the after-histories consisted only of statements that the patients were in good health at some specified time after operation, and 120 cases in which no after-history was given. For the preparation of the after-history statistics the 392 cases only are employed. In the majority of these cases the questions relating to the after-history were all answered, but as in a certain number of cases some of the questions were left unanswered, the statistics in the following tables have been worked out as percentages of the numbers of the answers to the respective questions.

The after-history inquiries were directed to the elucidation of the same points as in comnexion with the duodenal ulcers (see Part I, British Medical Journal, December 7th, 1929, p. 1075).

TABLE X.-I'ain or Other Discomfort Aftcr Food. (Information on these points was given in 375 cases.)

\begin{tabular}{|c|c|c|}
\hline & No. of Cases. & Percentage. \\
\hline No pain o: discomfort ... & 250 & 74.5 \\
\hline Occasional slight pain or discomfort & 50 & $15.0^{\circ}$ \\
\hline $\begin{array}{l}\text { Temporary pain or discomfcrt (in mos } \\
\text { cases soon after operation) }\end{array}$ & 23 & 7.0 \\
\hline Severe pain or discomfort & 12 & 3.5 \\
\hline
\end{tabular}

ThabLe XI.-Diurrhoca.

(Diarrhoca occurrecl in 18 cases out of the 392 .)

\begin{tabular}{|c|c|c|c|c|c|c|c|c|}
\hline \multicolumn{2}{|c|}{ Diarrhoea: } & \multicolumn{5}{|c|}{ - } & \multirow{3}{*}{$\begin{array}{c}\text { No. of Cases. } \\
16 \\
2\end{array}$} & \multirow{3}{*}{$\begin{array}{c}\text { Percentage } \\
4.1 \\
0.5\end{array}$} \\
\hline Siight ... & $\ldots$ & $\ldots$ & ... & $\ldots$ & $\ldots$ & $\ldots$ & & \\
\hline Severe ... & $\ldots$ & $\ldots$ & $\ldots$ & $\ldots$ & $\ldots$ & $\ldots$ & & \\
\hline
\end{tabular}

TABEE X!I-C̈onstipation.

(Constipation occurred in 54 cases out of the 392.)

\begin{tabular}{|c|c|c|c|c|c|c|c|c|}
\hline \multicolumn{7}{|c|}{ Constipation. } & No. of Cases. & Percentage. \\
\hline slight $\ldots$ & $\ldots$ & $\ldots$ & $\ldots$ & ... & $\ldots$ & $\ldots$ & 46 & 11.7 \\
\hline Sevcre ... & $\ldots$ & $\ldots$ & $\ldots$ & $\ldots$ & $\ldots$ & $\ldots$ & 8 & 2.0 \\
\hline
\end{tabular}

Tabre XllI.-Food Alje to be Taken. (Information as to diet was given in 330 cases.)

\begin{tabular}{lllllll|c|c}
\hline & No. of Cases. & Percentage. \\
\hline rull diet & $\ldots$ & $\ldots$ & $\ldots$ & $\ldots$ & $\ldots$ & $\ldots$ & 242 & 73.3 \\
Ceriain articles of diet avoided & $\ldots$ & $\ldots$ & 88 & 26.7 \\
\hline
\end{tabular}

Among the 88 cases in which some modification of the diet was necessary, 45 avoided some form or forms of protein food (beef, mutton, veal, pork, bacon, cheese, eggs), 31 avoided some form or forms of carbohydrate food (vegetables, pastry, fats, fruits), and 12 avoided some form or forms of both protein and carbohydrate foods. Therefore, of those on a modified diet, 51 per cent. were obliged to avoid some form of protein, 35 per cent. some form of carbohydrate, and 14 per cent. some form of both protein and carbohydrate.

Information as to the time of return to work afte operation was given in 280 cases. In a certain number of other cases it was stated that the individuals were either of the leisured classes doing no work, or were past the age for work. The particulars are given in the following table.

Table XIV.-Time of Return to Work After Operation.

\begin{tabular}{|c|c|c|c|c|c|c|c|c|c|}
\hline \multicolumn{8}{|c|}{ Time of Return to Work. } & \multirow{2}{*}{ No. of Cases. } & \multirow{3}{*}{ 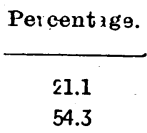 } \\
\hline 1 to $2 \mathrm{~m}$ & onth & & $\ldots$ & $\ldots$ & ... & ... & $\ldots$ & & \\
\hline 2 to 3 & $n$ & & $\ldots$ & $\ldots$ & $\ldots$ & ... & ... & & \\
\hline 3 to 4 & " & $\ldots$ & $\ldots$ & $\ldots$ & $\ldots$ & $\ldots$ & $\ldots$ & 34 & 12.1 \\
\hline 4 to 6 & $"$ & $\ldots$ & $\ldots$ & $\ldots$ & $\ldots$ & $\ldots$ & $\ldots$ & 23 & 8.2 \\
\hline Over 6 &. & & .. & & $\ldots$ & $\ldots$ & $\ldots$ & 12 & 4.3 \\
\hline
\end{tabular}

This table shows that 75.4 per cent. returned to work within three months from the date of the operation. With regard to those that did not return to work till after three months, the reasons given in many of the cases were that there was no immediate necessity for return, or that work was not available at the time.

TABLE XV.-Work Capacity.

(Information on this point was given in 310 cases.)

\begin{tabular}{lllllll|r|r}
\hline Work Capacity. & & & & & No. of Cases. & Percentage. \\
\hline Full work & $\ldots$ & $\ldots$ & $\ldots$ & $\ldots$ & $\ldots$ & $\ldots$ & 285 & 92.0 \\
Light work & $\ldots$ & $\ldots$ & $\ldots$ & $\ldots$ & $\ldots$ & $\ldots$ & 21 & 6.7 \\
Unable to work & $\ldots$ & $\ldots$ & $\ldots$ & $\ldots$ & $\ldots$ & 4 & 1.3 \\
\hline
\end{tabular}

TABLE XVI.-Woight Aftcr Opcration. (Information on this point was given in 327 cases.)

\begin{tabular}{|c|c|c|c|c|c|c|c|c|}
\hline Weight & & & & & & & No. of Cases. & Percentage. \\
\hline Gained ... & $\ldots$ & $\ldots$ & $\ldots$ & ... & ... & $\ldots$ & 245 & 74.9 \\
\hline Constant & ... & $\ldots$ & $\ldots$ & $\ldots$ & $\ldots$ & $\ldots$ & 61 & 18.7 \\
\hline Lost $\quad \ldots$ & . & $\ldots$ & $\ldots$ & $\ldots$ & $\ldots$ & $\ldots$ & 21 & 6.4 \\
\hline
\end{tabular}

TAeLE XVII.-C'ondition of H calth and W cll-bcing After Operation. (Information on this point was given in 332 cases:)

\begin{tabular}{|c|c|c|c|c|}
\hline Health. & & & No. of Cases. & Percentage. \\
\hline General impiovement of health & $\ldots$ & $\ldots$ & 298 & 89.8 . \\
\hline Fair improvement of health ... & ... & $\ldots$ & 11 & $3.3^{\circ}$ \\
\hline Slight improvement of health & $\ldots$ & .. & 13 & 3.9 \\
\hline No improvement of health ... & $\ldots$ & $\ldots$ & 10 & 3.0 \\
\hline
\end{tabular}

Subsequent Medical Treatment Required.

A few cases required laxatives, astringents, and occasional bismuth and sodium bicarbonate. Several cases had subsequent medical treatment, but the nature of it was not specified.

TABLE XVIII.-Number of Ycars Aftcr Opcration during which

Patients were under Obscration, or during which Rctiable Information was Obtaincd.

(Definite iriormation on this noint was given in 331 cases.)

\begin{tabular}{cccccccc|c|c}
\hline \multicolumn{3}{c}{ Years under Observation. } & & No. of Cases. & Percentage. \\
\hline $2-3$ sears & $\ldots$ & $\ldots$ & $\ldots$ & $\ldots$ & $\ldots$ & $\ldots$ & 9 & 2.7 \\
$3-4$ & $\ldots$ & $\ldots$ & $\ldots$ & $\ldots$ & $\ldots$ & $\ldots$ & $\ldots$ & 41 & 12.4 \\
$4-5$ & $\ldots$ & $\ldots$ & $\ldots$ & $\ldots$ & $\ldots$ & $\ldots$ & $\ldots$ & 87 & 26.2 \\
$5-6$ & $\ldots$ & $\ldots$ & $\ldots$ & $\ldots$ & $\ldots$ & $\ldots$ & $\ldots$ & 76 & 23.0 \\
$6-7$ & $\ldots$ & $\ldots$ & $\ldots$ & $\ldots$ & $\ldots$ & $\ldots$ & $\ldots$ & 56 & 16.9 \\
$7-8$ & $\ldots$ & $\ldots$ & $\ldots$ & $\ldots$ & $\ldots$ & $\ldots$ & $\ldots$ & 41 & 12.4 \\
$8-9$ & $\ldots$ & $\ldots$ & $\ldots$ & $\ldots$ & $\ldots$ & $\ldots$ & $\ldots$ & 21 & 6.4 \\
\hline
\end{tabular}

This tabie shows that 85 per cent. of the patients were under reliable observation for periods ranging from four to nine years.

Classification of Results.

The classification adopted is the same as that used in connetion with duodenal ulcers (see Part I, British Medical Journal, December 7th, 1929, p. 1076).

TABLE XIX.-Classification of Results.

(The results returned enabled this classification to be macle in 334 cases.)

\begin{tabular}{|llllllll|r|r}
\hline \multicolumn{3}{c}{ Classification. } \\
\hline Verg good & $\ldots$ & $\ldots$ & $\ldots$ & $\ldots$ & $\ldots$ & $\ldots$ & 248 & No. of Cases. & Percentage. \\
\hline Good & $\ldots$ & $\ldots$ & $\ldots$ & $\ldots$ & $\ldots$ & $\ldots$ & $\ldots$ & 54 & 74.3 \\
Fair & $\ldots$ & $\ldots$ & $\ldots$ & $\ldots$ & $\ldots$ & $\ldots$ & $\ldots$ & 18 & $16.1 \ldots$ \\
Pojr & $\ldots$ & $\ldots$ & $\ldots$ & $\ldots$ & $\ldots$ & $\ldots$ & $\ldots$ & 14 & 5.4 \\
\hline
\end{tabular}

These are the late result; of the various operations enumerated in Table $V$, and were obtained from the cases in which after-histories were given. As the main merits 
of the varions operations are represented by the percentage of "rery good" results, in that ther show the number of patients restored to full health, able to eat anything over periods of some rears, and able to resume full work, it was considcred advisable to compare the "very good", results in the three mincipal operations performed, together with the respective post-operative mortality. The three operations which constitute 92 per cent. of all the operations that were performed are: (1) posterior gastroenterostomy combined with excision, cauterization, or infolding of the ulcer; (2) partial gastrectomy with anastomosis to jejunum; and (3) posterior gastro-enterostomy without interference with the ulcer. These statistics have been worked out, and are embodied in the following table.

\begin{tabular}{|c|c|c|}
\hline Operation. & $\begin{array}{l}\text { Very good results } \\
\text { (percentage of } \\
\text { the cases, with } \\
\text { after-histories). }\end{array}$ & $\begin{array}{l}\text { Post-operative } \\
\text { Mortality } \\
\text { (percentage of } \\
\text { all cases). }\end{array}$ \\
\hline $\begin{array}{l}\text { Posterior gastro-enterostomy com- } \\
\text { bined with excision, cauterization } \\
\text { or infolding of ulcer } \\
\text { Partial gastrectomy with anasto- }\end{array}$ & $\begin{array}{l}91.7 \\
63.6\end{array}$ & 4.6 \\
\hline $\begin{array}{l}\text { Partial gastrectomy with anasto- } \\
\text { mosis to jejumum }\end{array}$ & 63.6 & \\
\hline $\begin{array}{l}\text { Posterior gasiro-enterostomy with- } \\
\text { out interference with the ulcer }\end{array}$ & 50.9 & 11.4 \\
\hline
\end{tabular}

This table shows that the opcration of posterior gastroenterostomy, combined with removal or infolding of the ulcer, gives the best results and the lowest mortality in the operative treatment of gastric ulceration, whereas the operation of posterior gastro-enterostomy without interference with the ulcer gives poor results and a very high mortality. As to the position of the operation of partial gastrectomy in this table it is only right to mention that the results in connexion with that operation are based on 101 cases only. For explanation of the post-operative mortality column in this table reference should be made to Table XXY1 in this report.

\section{Occupation.}

The occupations were given in 525 cases of gastric ulceration, including the cases of hour-glass constriction and perforation, and have been classified as follows.

Table XXI.-Occupational Incidence.

\begin{tabular}{|c|c|c|c|c|c|c|c|}
\hline \multicolumn{6}{|c|}{ Occupation. } & \multirow{2}{*}{$\frac{\text { No. of Cases. }}{163}$} & \multirow{2}{*}{$\frac{\text { Percentage. }}{31.0}$} \\
\hline Dome :tic worker & $\ldots$ & $\ldots$ & $\cdots$ & $\cdots$ & $\cdots$ & & \\
\hline Mechanics and sl & illes & arti: & & $\ldots$ & $\ldots$ & 81 & 15.4 \\
\hline Labourers $\quad \ldots$ & $\cdots$ & $\ldots$ & $\cdots$ & $\cdots$ & $\cdots$ & 80 & 15.3 \\
\hline Shop worker... & $\cdots$ & $\ldots$ & $\cdots$ & $\ldots$ & $\ldots$ & 42 & 8.0 \\
\hline Factory wor'iers & $\ldots$ & $\ldots$ & $\ldots$ & $\ldots$ & .. & 40 & 7.6 \\
\hline Clerks.. & $\ldots$ & $\ldots$ & & $\ldots$ & $\ldots$ & 21 & 4.0 \\
\hline Farmers and land & wo & ers & $\ldots$ & $\cdots$ & .. & 20 & 3.8 \\
\hline Professional and & eist & $\mathrm{e} 1 \mathrm{c}$ & sses & $\ldots$ & .. & 9 & 1.7 \\
\hline Miners ... $\ldots$ & $\ldots$ & $\ldots$ & $\ldots$ & $\ldots$ &.. & 3 & 0.6 \\
\hline Various cccupatio & $n$ & $\ldots$ & $\cdots$ & $\cdots$ & $\ldots$ & 66 & 12.6 \\
\hline
\end{tabular}

Domostic workers (female) were responsible for 15 per cent. of the duodenal and pyloric ulcers, whereas it will be seen from the above table that the same class is responsible for $31 \mathrm{per}$ cent. of the gastric ulcers. The total number of females in the gastric ulcer group is 192, of which 163-that is, 85 per cent.-were domestic workers. The great majority of the returns received in this investigation are of hospital patients, so that the above figures give no indication as to the occurrence of the disease among the bulk of the middle and upper classes.

Secondary Gastro-je junal Ulcers.

Number.-Three ulcers of this type-that is, 0.8 per cent. -occurred among the 392 cases in which after-histories were given.

Sex.-Two males and one female.

Age.-Two between 40 and 50 years of age, and one between 50 and 60 .
symptoms.-Pain in all three cases, romiting in one case, and haematemesis in one case.

Periods after Original Operation at which Symptoms occurred necessitating Operation for Gastro-jejunal Vlceration.-The periods in the three cases were respectively one year, one year and nine months, and one rear and ten months.

Operation.-Partial gastrectomy with good recovery in the three cases.

Second Operations required for Intercurrent Lesions after the Original Operation for Gastric Ulceration.

Seren of these operations-that is, 1.8 per cent.-were required among the 392 cases in which after-histories were given. One was between 20 and 30 years of age, one between 30 and 40, four between 40 and 50, and one between 50 and 60 . Particulars of the individual cases are given.

1. Persistent romiting for eight weeks after first operation. Stoma resected; death five days later from peritonitis due to a leak.

2. Pain, vomiting, and haematemesis three months after first operation from formation of a second gastric ulcer. Partial gastrectomy done; fair recovery.

3. Pain and vomiting one year after first operation from persistent lesser curve ulccr. Partial gastrectomy done; good recovery.

4. Pain and vomiting two years after first operation from persistent lesser curve ulcer. Partial gastrectomy done; good recovery.

5. Pain two and a half years after first operation from duodenal dilatation. Duodeno-jejunostomy done; good recovery.

6. Recurrence of symptoms four and a half years after first operation from a fresh ulcer. Excision done; good recovery.

7. Pain five years after first opcration from adhesions iuvolving transverse colon. Adhesions divided; good recovery.

\section{Secondary Haemorrhage.}

Number.-Four cases of secondary haemorrhage-that is, 1.0 per cent.-occurred among the 392 cases in which afterhistories were given.

sex. - Three males and one female.

Age.-One between 20 and 30 years of age, and three between 30 and 40 .

Nature of Haemorrhage.-Haematemesis in three cases, and melaena in one.

Periods at which Haemorrhage started after Operation. - One at ten days; one at nine months; one at four years; one had three attacks at one and a half years, five years, and six year's.

Treatment.-Three had medical treatment, and one had rest only; good recovery in all cases.

Analysis of the P'ost-operative Mortality.

Among the 538 cases of gastric ulceration 7 deaths occurred from another lesion some years after the operation and quite unconnected with it. As these 7 cases up to the time of death were free from all symptoms connected with the ulceration, these deaths are not included among the post-operative deaths.

The number of post-operative deaths out of the 538 cases was 48 -that is, 8.9 per cent. These are the deaths that occurred as a direct result of the operations for gastric ulcers, and do not include the one death from an intercurrent lesion previously referred to.

Sex.-Of the 48 deaths, 66.7 per cent. occurred amongst males, and 33.3 per cent. amongst females-a ratio which is the same as that of the sex incidence of the disease.

TABLE XXII.-Age Incidence of Deaths.

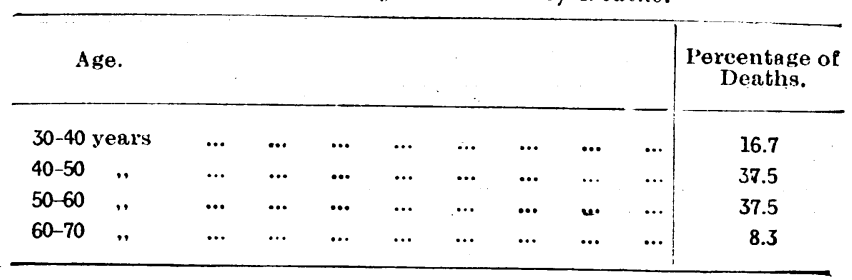


TABLE XXIII.-Time of Occurrcnce of Death After Operation.

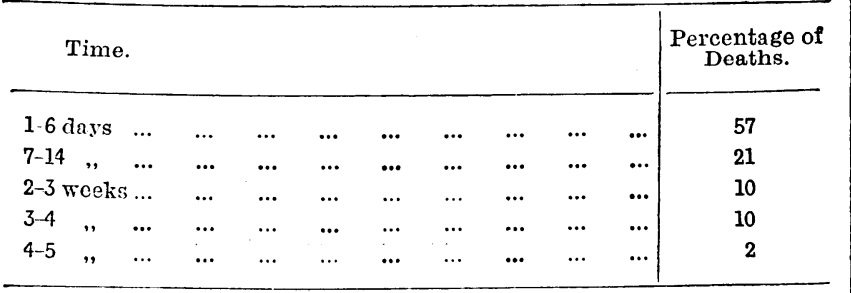

Among tio 49 cases lacmorihage occurred as a symptom prior to operation in 23 per cent. of the cases. It therefore appears, as in the cases of the duodenal and pyloric ulcers, that the risk of a fatal post-operative result is not increased by the occurrence of haemorrhage prior to the operation.

TABLE XXIV.-Cause of Dcath.

\begin{tabular}{|c|c|c|c|c|c|c|c|c|c|}
\hline \multicolumn{9}{|c|}{ Cause of Death. } & \multirow{2}{*}{$\frac{\text { No. of Cases. }}{19}$} \\
\hline Shock & $\ldots$ & $\ldots$ & $\ldots$ & $\ldots$ & $\ldots$ & $\ldots$ & ... & ... & \\
\hline Pneumonia & $\ldots$ & $\ldots$ & $\ldots$ & $\ldots$ & $\ldots$ & $\ldots$ & $\ldots$ & $\ldots$ & 6 \\
\hline Haematemesis & $\ldots$ & $\ldots$ & $\ldots$ & $\ldots$ & $\ldots$ & $\ldots$ & $\ldots$ & $\ldots$ & 5 \\
\hline \multicolumn{4}{|c|}{ Cardiac failure ( atty heart) } & $\ldots$ & $\ldots$ & $\ldots$ & $\ldots$ & $\ldots$ & 3 \\
\hline Bronchitis & $\cdots$ & $\cdots$ & $\ldots$ & $\ldots$ & $\ldots$ & $\cdots$ & ... & $\ldots$ & 1 \\
\hline Empyema & ... & $\ldots$ & $\ldots$ & $\ldots$ & $\ldots$ & $\ldots$ & $\cdots$ & $\ldots$ & 1 \\
\hline Tetany $\quad \ldots$ & $\ldots$ & $\ldots$ & $\ldots$. & $\ldots$ & $\ldots$ & $\ldots$. & $\ldots$ & $\ldots$ & 1 \\
\hline \multirow{2}{*}{\multicolumn{2}{|c|}{$\begin{array}{l}\text { Septic infec'ion } \\
\text { Enibolicm f ulm }\end{array}$}} & $\ldots$ & $\ldots$ & $\ldots$ & ... & $\ldots$ & $\therefore$ & $\therefore$ & 1 \\
\hline & & nar: & $\operatorname{artery}$ & $\ldots$ & $\ldots$ & $\ldots$ & $\ldots$ & $\therefore$ & 1 \\
\hline Hemiplegia & $\ldots$ & $\ldots$ & $\ldots$. & $\ldots$ & $\ldots$ & $\ldots$ & $\ldots$ & $\ldots$ & 1 \\
\hline Cause not stat & & $\cdots$ & $\ldots$ & $\ldots$ & $\therefore$ & $\ldots$ & $\ldots$ & $\ldots$ & 9 \\
\hline
\end{tabular}

Comparison of the Post-opercitive ilortality in Relation to the Site of the Gastric Ulcer.

If a comparison is made of the post-operative mortality occurring amongst ulcers according to their special positions or sites in the stomach, it appears that the mortality is much lower for lesser curvature ulcers and is much higher for ulcers on the posterior wall than the average postoperative mortality. This is shown in the following table.

Table XXV.

\begin{tabular}{llllll|c|c|c}
\hline \multicolumn{3}{c}{ Po-ition or Site of Ulcor. } & & & $\begin{array}{c}\text { No. of } \\
\text { Cases. }\end{array}$ & $\begin{array}{c}\text { No. of } \\
\text { Deaths. }\end{array}$ & $\begin{array}{c}\text { Percentage } \\
\text { of Deaths. }\end{array}$ \\
\cline { 1 - 2 } Lesser currature & $\ldots$ & $\ldots$ & $\ldots$ & $\ldots$ & 377 & 19 & 5.0 \\
Anterior wall & $\ldots$ & $\ldots$ & $\ldots$ & $\ldots$ & $\ldots$ & 16 & 1 & 6.2 \\
Near pylorus & $\ldots$ & $\ldots$ & $\ldots$ & $\ldots$ & $\ldots$ & 56 & 6 & 10.7 \\
Cardiac end & $\ldots$ & $\ldots$ & $\ldots$ & $\ldots$ & $\ldots$ & 14 & 2 & 14.3 \\
Posterior wa!l & $\ldots$ & $\ldots$ & $\ldots$ & $\ldots$ & $\ldots$ & 55 & 13 & 23.6 \\
\hline
\end{tabular}

Comparison of the Post-operative Mortality of the Three Principal Operations.

The 8.9 per cent. mortality represents the death rate after the performance of the 538 operations detailed in Table V. Of these operations, 129 were posterior gastroenterostomy, combined with excision, cauterization, or infolding of the ulcer; 101 were partial gastrectomy with anastomosis to jejunum; 263 were posterior gastroenterostomy without any interference with the ulcer; and 45 were other operations (mainly anterior gastroenterostomy). The comparison of the post-operative mortality of the three principal operations, as shown in the following table, has already been referred to in Table XX.

TABLE XXVI.

\begin{tabular}{|c|c|c|c|}
\hline Type of Operation. & $\begin{array}{l}\text { No. of } \\
\text { Cases. }\end{array}$ & $\begin{array}{c}\text { No. of } \\
\text { Deaths. }\end{array}$ & $\begin{array}{l}\text { Percentage } \\
\text { of Deaths. }\end{array}$ \\
\hline $\begin{array}{l}\text { Posterior gastro-enterostomv combined } \\
\text { with excision, cauterization, or infold- } \\
\text { ing of ulcer }\end{array}$ & 129 & 6 & 4.6 \\
\hline $\begin{array}{l}\text { Partial gastrectomy with anastomosis to } \\
\text { jejunum }\end{array}$ & 101 & 6 & 6.0 \\
\hline $\begin{array}{l}\text { Posterior gastro-enterostomy without in- } \\
\text { terference with the u'cer }\end{array}$ & 263 & 30 & 11.4 \\
\hline $\begin{array}{l}\text { Other operations (mainly anterior gastro- } \\
\text { entercstomy) }\end{array}$ & 45 & 6 & 13.3 \\
\hline
\end{tabular}

If these death percentages are proportionately averaged the 8.9 per cent. post-operative mortality for the whole of the cases is obtained. These figures show, so far as any useful deductions can be drawn from groups of 129 and 101 cases, that the operation of posterior gastroenterostomy, combined with removal or infolding of the ulcer, has the lowest mortality, while that of posterior gastro-enterostomy alone has a very high mortality.

Carcinoma Developing at the Site of Ulcers.

No authenticated case was reported in the whole series. In one case the patient, aged 69 at the time of death, developed gastric pain nearly four years after the operation for gastric ulcer. A laparotomy was done and a hard non-removable mass was felt at the site of the old ulcer. Death occurred on the following day from shock. In answer to a special letter sent to the surgeon who had charge of the case, he replied that he could give no opinion as to the nature of the mass.

In a second case the patient, aged 36 years at the time of operation, developed symptoms five years after operation, and a diagnosis was made by $x$-ray examination of inoperable carcinoma of the stomach. The patient continued to lose weight, and the mass was easily palpable. Death occurred one year after the commencement of the fresh symptoms, but no post-nortem examination was held.

\section{Brief Summary of Results.}

Gastric ulceration is twice as common in males as in females.

The liability to gastric ulceration rapidly diminishes after 50 years of age, as is also the case with both duodenal and pyloric ulceration.

Posterior gastro-cnterostomy, with or without removal or infolding of the ulcer, was performed in 73 per cent. of the cases, and partial gastrectomy with anastomosis to jejunum in 19 per cent.

Vomiting (with or without haemorrhage) was a symptom in 93 per cent. of the cases, as compared with 53 per cent. amongst the duodenal ulcers, and 64 per cent. amongst the pyloric uोcers.

A low acidity of the gastric juice was present in 60 per cent. of the cases submitted to test meals.

Neither diarrhoea nor constipation is a marked result of operation, but, as in the cases of duodenal and pyloric ulcers, constipation of a mild character is more frequent than riarrhoea.

About one-quarter of the patients operated on made some modification in diet. Of these, 51 per cent. avoided some form of protein, 35 per cent. some form of carbohydrate, and 14 per cent. some form of both protein and carbohydrate.

Three-fourths of the patients returned to full work within three months of the date of the operation.

General improvement of health and well-being occurred in 90 per cent. of the cases with after-histories.

The operation of posterior gastro-enterostomy, combined with removal or infolding of the ulcer, gives the best results and the lowest mortality.

Secondary gastro-jejunal ulcers occurred in 0.8 per cent. of the cases, as compared with 2.8 per cent. for duodenal ulcers and 0.9 per cent. for pyloric ulcers.

Secondary haemorrhage occurred in 1.0 per cent. of the cases, as compared with 2.4 per cent. for duodenal ulcers and 1.2 per cent. for pyloric ulcers.

The post-operative mortality for all operations was 8.9 per cent., the mortality being highest in patients from 40 to 60 years of age. The operation of posterior gastroenterostomy, combined with removal or infolding of the ulcer, had a post-operative mortality of 4.6 per cent.; partial gastrectomy with anastomosis to jejunum had a post-operative mortality of 6.0 per cent.; posterior gastroenterostomy alone had a post-operative mortatity of 11.4 per cent.

No authenticated case of carcinoma developing at the site of an ulcer was reported in the whole series. 


\section{PaRT V.-HOUR-GLASS CONSTRICTION.}

As previously mentioned, it was considered advisable to prepare a separate report on these cases. The results may be of use for future reference, but as the number of the ases is comparatively small very few comments on the results are made.

TABLE I.-Sex Incidence.

$\begin{array}{llllllll}\text { Number of cases ... } & \ldots & \ldots & \ldots & \ldots & \ldots & \text { C5 }\end{array}$

$\begin{array}{lllllll}\text { Males (percentage) } & \ldots & \ldots & \ldots & \ldots & \ldots & 15.4\end{array}$

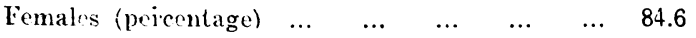

TABLE II.-Ige Incidence (et Time of Operation).

\begin{tabular}{|c|c|c|c|c|c|c|c|c|c|}
\hline Age. & & & & & & & & & Percentage. \\
\hline $20-30$ year's & $\ldots$ & $\ldots$ & $\ldots$ & $\ldots$ & $\ldots$ & $\ldots$ & $\ldots$ & $\ldots$ & 4.8 \\
\hline $30-40$ & $\ldots$ & $\ldots$ & $\ldots$ & $\ldots$ & $\ldots$ & $\ldots$ & $\ldots$ & $\ldots$ & 28.6 \\
\hline $40-50$ & $\ldots$ & $\ldots$ & $\ldots$ & $\ldots$ & $\ldots$ & ... & $\ldots$ & ... & 25.4 \\
\hline 50.60 & $\ldots$ & $\ldots$ & $\ldots$ & $\ldots$ & $\ldots$ & ... & ... & ... & 33.3 \\
\hline $60-70$ & $\ldots$ & $\ldots$ & $\ldots$ & $\ldots$ & $\ldots$ & $\ldots$ & $\ldots$ & $\ldots$ & 7.9 \\
\hline
\end{tabular}

TABLE HI.--Type: of Operation.

\begin{tabular}{|c|c|c|}
\hline Type of Operation. & No. of Cases. & Percentage. \\
\hline $\begin{array}{l}\text { Partigl gastrectomy with anastomosis to } \\
\text { jejunum }\end{array}$ & 33 & 50.7 \\
\hline $\begin{array}{llll}\text { Posterior gastro-enterostomy } \ldots & \ldots & \bullet \ldots & \ldots\end{array}$ & 13 & 20.0 \\
\hline Anterior gastro-enterostomy $\quad \ldots \quad \ldots$ & 9 & 13.8 \\
\hline $\begin{array}{l}\text { Post erior gastro-enterostomy and excision } \\
\text { of ulcer }\end{array}$ & 8 & 123 \\
\hline $\begin{array}{l}\text { Hour-glass incised longitudinally and sewn } \\
\text { transversely }\end{array}$ & 1 & 1.6 \\
\hline Double gastro-jejunostomy $\quad$... & 1 & 1.6 \\
\hline
\end{tabular}

In addition, appendicectomy was performed in 3.1 per cent. of the cases, and cholecystotomy in 3.1 per cent.

The reasons for operating were given in 55 cases. They are recorded in the following table.

TARLE IV.-Licasons for Operating.

\begin{tabular}{lllllll|c|c}
\hline \multicolumn{2}{c}{ Symptoms. } & & & & & & No. of Cases. & Percentage. \\
\hline Pain $\ldots$ & $\ldots$ & $\ldots$ & $\ldots$ & $\ldots$ & $\ldots$ & $\ldots$ & 53 & 96.3 \\
Vomiting & $\ldots$ & $\ldots$ & $\ldots$ & $\ldots$ & $\ldots$ & $\ldots$ & 46 & 83.6 \\
Haematemesis & $\ldots$ & $\ldots$ & $\ldots$ & $\ldots$ & $\ldots$ & 13 & 23.6 \\
Haematemesis and melaena & $\ldots$ & $\ldots$ & $\ldots$ & 2 & 3.6 \\
Loss of weight & $\ldots$ & $\ldots$ & $\ldots$ & $\ldots$ & $\ldots$ & 5 & 9.1 \\
\hline
\end{tabular}

The direct results of operation in the 65 cases were as follows.

TABLE V.-Results of Opcration.

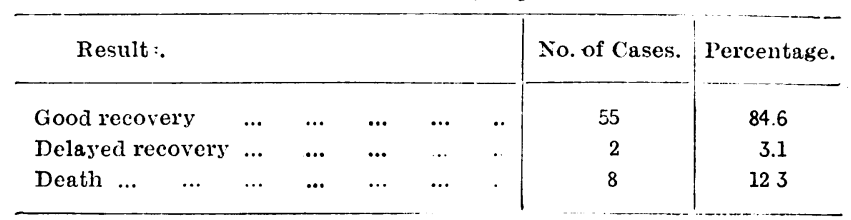

The results in 43 cases submitted to $x$-ray examination prior to operation are shown in the following table.

TABLE VI.-Results of X-Ray Examinations.

\begin{tabular}{|c|c|c|c|c|c|c|c|c|}
\hline Result. & & & & & & & & Perce::tage. \\
\hline Positive ... & $\ldots$ & .. & $\ldots$ & $\ldots$ & $\ldots$ & $\ldots$ &.. & 93.0 \\
\hline Negative .. & $\cdots$ & $\cdots$ & $\cdots$ & $\ldots$ & $\ldots$ & $\ldots$ & $\cdots$ & 2.3 \\
\hline Delay in emptying & $\ldots$ & $\ldots$ & $\ldots$ & $\ldots$ & $\ldots$ & $\ldots$ &.. & 4.7 \\
\hline
\end{tabular}

In 18 cases test meals were employed prior to operation. The results are shown in the following table.

Tadie VII.--Results of Trest Mrels.

\begin{tabular}{|c|c|c|c|c|c|c|c|}
\hline Result. & & & & & & & Percentage. \\
\hline Hyperchlorhydria $\quad \ldots$ & $\ldots$ & $\ldots$ & $\ldots$ & $\ldots$ & $\ldots$ & $\ldots$ & 16.7 \\
\hline Low acidity $\quad \ldots \quad \ldots$ & $\ldots$ & $\ldots$ & $\ldots$ & $\ldots$ & $\ldots$ & $\ldots$ & 77.8 \\
\hline No free hydrochloric acid & $\ldots$ & $\ldots$ & $\ldots$ & $\ldots$ & $\ldots$ & $\ldots$ & 5.5 \\
\hline
\end{tabular}

After-Histories of the Operition Cases.

The 65 cases include 52 cases in which the after-histories were given, 4 cases in which the after-histories consisted only of statements that the patients were in good health at some specified times after operation, and 9 cases in which no after-history was given. For the preparation of the after-history statistics the 52 cases only are emploved, and, as in the previous reports, the statistics have been worked out as percentages: of the numbers of the answers to the respective questions.

'Table VIII.-Pain or Other Discomfort After Food. (Information on these points was given in 44 cases.)

\begin{tabular}{|c|c|c|c|}
\hline & & No. of Cases. & Pereentage. \\
\hline No pain or discomfort $\ldots$ & $\ldots$ & 38 & 86.3 \\
\hline Occasional slight pain or discomfort & $\ldots$ & 4 & 9.1 \\
\hline Temporary pain or discomfort & ... & 1 & 2.3 \\
\hline Severe pain or discomfort & $\ldots$ & 1 & 2.3 \\
\hline
\end{tabular}

Diarrhoca.-Slight diarrhoea occurred in 2 cases out of the 52 .

Constipation.-Slight constipation occurred in 7 cases out of the 52 .

Table IX.Frod Able to be Talien.

(Information as to diet was given in 44 cases.)

\begin{tabular}{lrrrrr|c|c}
\hline & & & No. of Cases. & Pcrcentage. \\
\hline Full diet $\quad \ldots$ & $\ldots$ & $\ldots$ & $\ldots$ & $\ldots$ & $\ldots$ & 37 & 84.1 \\
15.9
\end{tabular}

TABLE X.-Time of Rrturn to Work After Operation. (Information was given in 42 cases.)

\begin{tabular}{|c|c|c|c|c|c|c|c|c|}
\hline \multicolumn{7}{|c|}{ Time of Return to Work. } & \multirow{2}{*}{$\frac{\text { No. of Cases. }}{5}$} & \multirow{2}{*}{$\begin{array}{c}\text { Percentage. } \\
119\end{array}$} \\
\hline 1 to $2 \mathrm{~m}$ & onths & $\ldots$ & $\ldots$ & $\ldots$ & $\ldots$ & $\ldots$ & & \\
\hline 2 to 3 & " & $\ldots$ & ... & $\ldots$ & ... & $\ldots$ & 27 & 64.3 \\
\hline 3 to 4 & " & $\ldots$ & $\ldots$ & $\ldots$ & $\ldots$ & $\ldots$ & 4 & 95 \\
\hline 4 to 6 & " & $\ldots$ & ... & ... & ... & $\ldots$ & 4 & 9.5 \\
\hline Over 6 & " & $\ldots$ & $\ldots$ & $\ldots$ & $\cdots$ & $\ldots$ & 2 & 4.8 \\
\hline
\end{tabular}

This table shows that 76.2 per cent. returned to work within three months from the date of the operation.

Table XI.-Work Cupacity. (Information on this point was given in 43 cases.)

\begin{tabular}{|c|c|c|c|c|c|c|c|c|}
\hline \multicolumn{7}{|c|}{ Work Capacity. } & No. of Cases. & Tercentage. \\
\hline Full work & ... & $\cdots$ & ... & $\cdots$ & $\ldots$ & $\cdots$ & 40 & 93.0 \\
\hline Light work & $\ldots$ & $\ldots$ & $\ldots$ & $\ldots$ & $\ldots$ & $\ldots$ & 3 & 70 \\
\hline
\end{tabular}

Table XII.-Wright Affer Operation.

(Information on this point was given in 43 casss.)

\begin{tabular}{|c|c|c|c|c|c|c|c|c|}
\hline \multicolumn{4}{|c|}{ Weight. } & \multicolumn{3}{|c|}{$\therefore$} & No. of Cases. & i'crcentase. \\
\hline Gained ... & $\ldots$ & $\ldots$ & $\ldots$ & $\ldots$ & $\ldots$ & $\ldots$ & 37 & 86.0 \\
\hline Constant & $\ldots$ & $\ldots$ & $\ldots$ & $\ldots$ & $\ldots$ & $\ldots$ & 4 & 93 \\
\hline Lost $\quad \ldots$ & $\ldots$ & $\ldots$ & $\ldots$ & $\ldots$ & $\ldots$ & $\ldots$ & 2 & 4.7 \\
\hline
\end{tabular}


T'ABLE XIII.-C'ondition of Health and W, ll-bring After Operation. (Information on this point was given in 43 cases.)

\begin{tabular}{|c|c|c|c|c|}
\hline Health. & & & No. of Cases. & Percentage. \\
\hline General improvement of health & $\ldots$ & $\ldots$ & 39 & 90.7 \\
\hline Fair improvement of health ... & ... & $\ldots$ & 2 & 4.7 \\
\hline Slight improvement of health & $\ldots$ & $\ldots$ & 1 & 2.3 \\
\hline No improvement of health $\ldots$ & $\cdots$ & $\cdots$ & 1 & 2.3 \\
\hline
\end{tabular}

'ABLE XIV. Number of Years After Operation during which Paticnts ucre under Observation, or during which Reliable Information use Obtuincd.

(Definite information was given in 41 cases.)

\begin{tabular}{|c|c|c|c|c|c|c|c|c|c|}
\hline \multicolumn{8}{|c|}{ Years under Observation. } & \multirow{2}{*}{ No. of Cases. } & \multirow{2}{*}{ Percentage. } \\
\hline $1-2 \mathrm{y}$ & ears & $\ldots$ & $\ldots$ & $\ldots$ & $\ldots$ & $\ldots$ & $\ldots$ & & \\
\hline $2-3$ & ", & $\ldots$ & $\ldots$ & $\ldots$ & $\ldots$ & $\ldots$ & .. & 1 & 2.4 \\
\hline $3-1$ & " & $\ldots$ & $\ldots$ & $\ldots$ & $\ldots$ & $\ldots$ & $\ldots$ & 2 & 4.9 \\
\hline $4-5$ & $"$ & $\cdots$ & $\ldots$ & $\ldots$ & $\ldots$ & $\ldots$ & $\ldots$ & 14 & 34.1 \\
\hline $5-6$ & ", & $\cdots$ & $\ldots$ & $\ldots$ & $\ldots$ & $\ldots$ & $\ldots$ & 9 & 22.0 \\
\hline $6 \cdot 7$ & " & $\ldots$ & $\ldots$ & $\ldots$ & $\ldots$ & $\ldots$ & $\ldots$ & 5 & 12.2 \\
\hline $7-8$ & " & $\ldots$ & $\ldots$ & $\ldots$ & $\ldots$ & $\ldots$ & $\ldots$ & 3 & 7.3 \\
\hline $8-9$ & " & $\cdots$ & $\cdots$ & $\cdots$ & $\cdots$ & $\cdots$ & $\cdots$ & 6 & 14.7 \\
\hline
\end{tabular}

TABLE XV.-C'lessification of Results.

(The results returned enabled this classification to be made in 43 cases.)

\begin{tabular}{llllllll|c|c}
\multicolumn{3}{c}{ Classification. } & & & & & No. of Cases. & Percentaje. \\
\hline Very good & $\ldots$ & $\ldots$ & $\ldots$ & $\ldots$ & $\ldots$ & $\ldots$ & 36 & 83.7 \\
Good & $\ldots$ & $\ldots$ & $\ldots$ & $\ldots$ & $\ldots$ & $\ldots$ & $\ldots$ & 3 & 70 \\
Fair & $\ldots$ & $\ldots$ & $\ldots$ & $\ldots$ & $\ldots$ & $\ldots$ & $\ldots$ & 3 & 7.0 \\
Poor & $\ldots$ & $\ldots$ & $\ldots$ & $\ldots$ & $\ldots$ & $\ldots$ & $\ldots$ & 1 & 2.3 \\
\hline
\end{tabular}

The same comparison follows as was made in Part IV of the "very good" results and the respective postoperative mortality of the various operations performed.

\begin{tabular}{|c|c|c|}
\hline Operation. & $\begin{array}{l}\text { Very good results } \\
\text { (percentage of } \\
\text { the cases with } \\
\text { after-histories). }\end{array}$ & $\begin{array}{l}\text { Post-operative } \\
\text { mor ality } \\
\text { (percenta;e of } \\
\text { all cases). }\end{array}$ \\
\hline Posterior gastro enterost $\mathrm{my}$ com- & 875 & 12.5 \\
\hline $\begin{array}{l}\text { bined with excision of ulcer } \\
\text { Partial gastrectomy with anasto- } \\
\text { mosis to jejuntmm }\end{array}$ & 57.6 & 15.1 \\
\hline Posterior gastro-e-ter -stomy $\quad \ldots$ & 461 & 7.7 \\
\hline Anterior ga tro-enterosto ny & 44.4 & 111 \\
\hline
\end{tabular}

Analysis of the Post-operative Mortality.

The number of post-operative deaths out of the 65 cases was 8 -that is, 12.3 per cent.

Sex.-. Of the 8 deaths, 3 occurred amongst males and 5 amongst females.

Age Incidence of Deaths.-Half occurred between 40 and 50 years of age, and half between 50 and 61 years of age.

Time of Occurrence of Death after Operation.--Séven deaths occurred botwcen one and scren days, and one death occured from broncho-pneumonia twonty-five days after operation.

Comperison of the Post-operative Martulity of the Furious
Opcrutions Performed.

If these death percentages are proportionately averaged the 12.3 per cent. post-operative mortality for the whole of the cases is obtained.

Carcinoma Developing at the Site of Ulcer.-No case was reported in the whole series.

\section{Brief Summary of Results.}

Hour-glass constriction is much more common in females.

The liability to hour-glass constriction is fairly constant from 30 to 60 years of age.

A low acidity of the gastric juice was present in a large majority of the cases tested.

76.2 per cent. of the cases returned to full work within three months of the date of the operation.

General improvement of health and well-being occurred in 90 per cent. of the cases with after-histories.

The post-operative mortality was 12.3 per cent.

No case of carcinoma developing at the site of an ulcer was reported in the whole series.

P VIT VI-PERFORATED GASTRIC ULCERS.

There were 42 reports of the results of operations for perforated gastric ulcer's. These results may be of use for future reference, but as the number of the cases is small the only comments on the results are given in the summary at the end.

TABLE I.-Sex Incidence.

$\begin{array}{lllllll}\text { Number of cases } \ldots & \ldots & \ldots & \ldots & \ldots & \ldots & 42 \\ \text { Males (percentage) } & \ldots & \ldots & \ldots & \ldots & \ldots & 73.8 \\ \text { Females (percentage) } & \ldots & \ldots & \ldots & \ldots & \ldots & 26.2\end{array}$

TABLE II.-Age Incidcnce (at Time of Opcration).

\begin{tabular}{|c|c|c|c|c|c|c|c|c|c|c|}
\hline \multicolumn{10}{|c|}{ Age. } & \multirow{2}{*}{$\frac{\text { Percentage. }}{10.0}$} \\
\hline $20-30$ & ears & $\ldots$ & $\ldots$ & $\ldots$ & $\ldots$ & $\ldots$ & $\ldots$ & $\ldots$ & $\ldots$ & \\
\hline $30-70$ & " & $\ldots$ & $\ldots$ & $\ldots$ & $\ldots$ & $\ldots$ & ... & $\ldots$ &.. & 35.0 \\
\hline $40-50$ & , & $\ldots$ & $\ldots$ & $\ldots$ & $\ldots$ & ... & ... & $\ldots$ & $\ldots$ & 32.5 \\
\hline $50-60$ & , & $\ldots$ & $\ldots$ & $\ldots$ & $\ldots$ & $\ldots$ & ... & $\ldots$ & $\ldots$ & 20.0 \\
\hline 6070 & , & $\ldots$ & $\ldots$ & $\ldots$ & $\ldots$ & $\ldots$ & ... & $\ldots$ & $\ldots$ & 2.5 \\
\hline
\end{tabular}

Table III.-Position on Site of Ulcer. (Information on this point was given in 26 cases.)

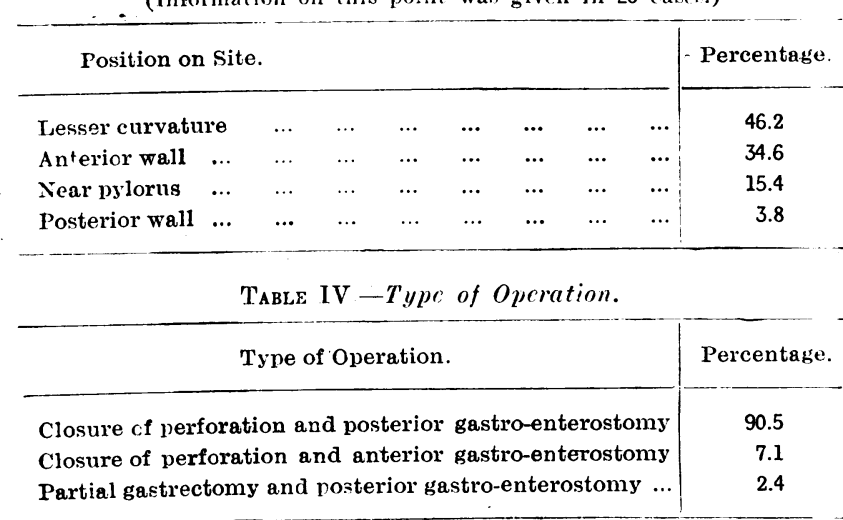

TABle V.-Rertsons for Operating.

Symptoms.

\begin{tabular}{llllllllll|r} 
Pain $\ldots$ & $\ldots$ & $\ldots$ & $\ldots$ & $\ldots$ & $\ldots$ & $\ldots$ & $\ldots$ & $\ldots$ & 100.0 \\
Vomitin. &, & &
\end{tabular}

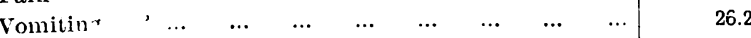

$\begin{array}{lllllllll}\text { Haema em } \mathrm{sis} \ldots & \ldots & \ldots & \ldots & \ldots & \ldots & \ldots & \ldots & 4.7\end{array}$

\begin{tabular}{llllllllll|r} 
Melaera & $\ldots$ & $\ldots$ & $\ldots$ & $\ldots$ & $\ldots$ & $\ldots$ & $\ldots$ & $\ldots$ & $\ldots$ & 2.4
\end{tabular}

TABLE VI.-Results of Operation.

Pesult.

Good recovery ...

Death
Percent gie.

71.4 28.6 
Aftri-Historifs of the Operation Cases.

The 42 cases dealt with in the above tables include 34 cases in which the after-histories were given, and 8 cases in which no after-history was given. For the preparation of the after-history statistics the 34 cases only are employed.

TañLe VII.-Pain or Other Discomfort After Food.

(Inforination on these points was given in 22 cases.)

\begin{tabular}{|c|c|}
\hline & Percestage. \\
\hline No pain or discomfort & 546 \\
\hline Occasional or slight pain or discomfo: $t$ & 31.8 \\
\hline $\begin{array}{l}\text { Temporary pain or discomfort (in most cases soon after } \\
\text { operation) }\end{array}$ & 13.6 \\
\hline
\end{tabular}

Diarrhoea.-Slight diarrhoea occurred in 3.0 per cent. of the cases.

Constipation.-Slight constipation occurred in 11.8 per cent. of the cases.

Table VIII.-Food able to be Tulien. (Information as to diet was given in 21 cases.)

\begin{tabular}{|c|c|c|c|c|c|}
\hline & & & & & Percentage. \\
\hline Full diet ... & $\ldots$ & $\ldots$ & ... & $\ldots$ & 71.4 \\
\hline Certain artic!cs of dit $\mathrm{t}$ avoided ... & $\ldots$ & $\ldots$ & $\ldots$ & $\ldots$ & 28.6 \\
\hline
\end{tabular}

TABle IX.-Time of Return to Work After Opcration. (Information on this point was given in 21 cascs.)

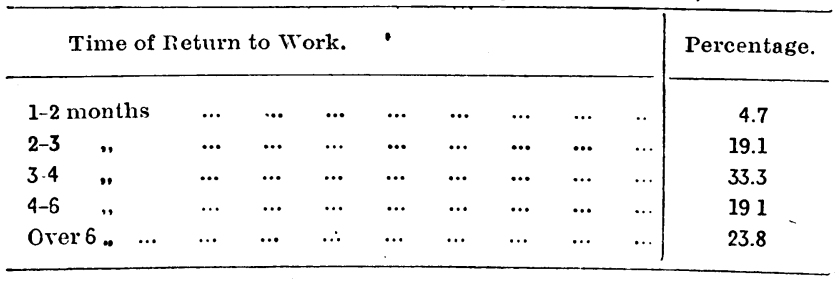

TABLE X.-Work Capacity.

(Information on this point was given in 22 cases.)

\begin{tabular}{|c|c|c|c|c|c|c|c|c|c|}
\hline \multicolumn{9}{|c|}{ Work Caracty. } & \multirow{3}{*}{$\begin{array}{c}\text { Percentage. } \\
\begin{array}{c}\varepsilon 6.4 \\
13.6\end{array}\end{array}$} \\
\hline Full work... & $\cdots$ & $\cdots$ & $\cdots$ & $\cdots$ & $\cdots$ & $\cdots$ & $\cdots$ & $\cdots$ & \\
\hline Light work & $\cdots$ & $\cdots$ & $\cdots$ & $\cdots$ & $\cdots$ & $\cdots$ & $\cdots$ & $\cdots \mid$ & \\
\hline \multicolumn{10}{|c|}{$\begin{array}{l}\text { TABLE XI.- Weight After Operation. } \\
\text { (Information on this point was given in c0 cases.) }\end{array}$} \\
\hline weight. & & & & & & & & & Percentage. \\
\hline Gained $\quad \ldots$ & $\cdots$ &.. & $\ldots$ & $\ldots$ & $\cdots$ & $\ldots$ & $\ldots$ & $\ldots$ & 550 \\
\hline Cons'ant ... & $\cdots$ & $\cdots$ & $\cdots$ & $\ldots$ & $\cdots$ & $\cdots$ & $\cdots$ & $\ldots$ & 40.0 \\
\hline Lost... & $\cdots$ & $\cdots$ & $\cdots$ & $\cdots$ & $\cdots$ & $\cdots$ & $\cdots$ & $\ldots$ & 5.0 \\
\hline
\end{tabular}

TABLE XII.-Condition of Health and Well-being After Operation. (Information on this point was given in 22 eases.)

\begin{tabular}{cccccc|c}
\hline Health. & & & & & & Percentage. \\
\hline General improvement of health & $\ldots$ & $\ldots$ & $\ldots$ & $\ldots$ & $\ldots$ & 773 \\
Fair improvement of hea'th & $\ldots$ & $\ldots$ & $\ldots$ & $\ldots$ & $\ldots$ & 18.2 \\
Slight improvement of health & $\ldots$ & $\ldots$ & $\ldots$ & $\ldots$ & $\ldots$ & 4.5 \\
\hline
\end{tabular}

TABLE XIII.- Numbrr of Yrars After Oprration aring which Paticnts were under Obscrvation, or during which Reliable Information was Obtaincd.

(Definite information on this point was givon in 22 cases.)

\begin{tabular}{|c|c|c|c|c|c|c|c|c|c|c|c|}
\hline \multicolumn{11}{|c|}{ Years under Observation. } & \multirow{2}{*}{ Percentage. } \\
\hline $3-4$ & years & $\ldots$ & $\ldots$ & $\ldots$ & $\ldots$ & $\ldots$ & $\ldots$ & $\ldots$ & $\ldots$ & $\ldots$ & \\
\hline 4-5 & ", & $\ldots$ & $\cdots$ & $\cdots$ & $\cdots$ & $\cdots$ & $\cdots$ & $\ldots$ & $\ldots$ & ... & 18.2 \\
\hline $5-6$ & , & $\ldots$ & $\ldots$ & $\ldots$ & $\ldots$ & $\ldots$ & $\ldots$ & $\ldots$ & $\ldots$ & $\ldots$ & 13.6 \\
\hline $6-7$ & .. & $\ldots$ & $\ldots$ & $\ldots$ & $\ldots$ & $\ldots$ & $\ldots$ & $\ldots$ & $\ldots$ & $\ldots$ & 18.2 \\
\hline $7-8$ & .. & $\ldots$ & $\ldots$ & $\ldots$ & $\ldots$ & $\ldots$ & $\ldots$ & $\ldots$ & $\ldots$ & $\ldots$ & 13.6 \\
\hline $8-9$ & ,. & $\ldots$ & $\ldots$ & $\ldots$ & $\ldots$ & $\ldots$ & $\ldots$ & $\ldots$ & $\ldots$ & $\ldots$ & 4.6 \\
\hline
\end{tabular}

Table XIV.-Classification of Rcsults.

(The results returred cnabled this classification to be made in 22 cases.)

\begin{tabular}{lccccccccc|c}
\hline \multicolumn{3}{c}{ Classification. } \\
\hline Very goo $3 \ldots$ & $\ldots$ & $\ldots$ & $\ldots$ & $\ldots$ & $\ldots$ & $\ldots$ & $\ldots$ & $\ldots$ & Percentage. \\
\hline Good & $\ldots$ & $\ldots$ & $\ldots$ & $\ldots$ & $\ldots$ & $\ldots$ & $\ldots$ & $\ldots$ & $\ldots$ & 137 \\
Fair & $\ldots$ & $\ldots$ & $\ldots$ & $\ldots$ & $\ldots$ & $\ldots$ & $\ldots$ & $\ldots$ &.. & 18.2 \\
Poor & $\ldots$ & $\ldots$ & $\ldots$ & $\ldots$ & $\ldots$ & $\ldots$ & $\ldots$ & $\ldots$ &. & 4.5 \\
\hline
\end{tabular}

No secondary gastro-jejunal uleer occurred in the whole series.

No secondary haemorrhage occurred in the whole series.

Analysis of the Post-operative Mortality.

The number of post-operative deaths out of the 42 cases was 12 -that is, 28.6 per cent.

Ser.-Nine of the deaths occurred among males, and 3 among females.

TABLE XV.-A $y$. Incidence of Dcaths.

\begin{tabular}{|c|c|c|c|c|c|c|c|c|c|c|}
\hline \multicolumn{3}{|c|}{ Age. } & & & & & & & \multirow[b]{2}{*}{... } & $\begin{array}{l}\text { Percentage of } \\
\text { Deaths. }\end{array}$ \\
\hline \multicolumn{2}{|c|}{$20-30$ years } & $\ldots$ & $\ldots$ & $\ldots$ & $\ldots$ & ... & $\ldots$ & $\ldots$ & & 18.2 \\
\hline $30-40$ & ", & $\ldots$ & $\ldots$ & ... & .. & ... & ... & ... & $\ldots$ & 27.3 \\
\hline $40-50$ & , & $\ldots$ & $\ldots$ & ... & $\ldots$ & $\ldots$ & $\ldots$ & $\ldots$ & .. & 27.3 \\
\hline $50-60$ & , & $\ldots$ & $\ldots$ & $\ldots$ & $\ldots$ & $\ldots$ & $\ldots$ & $\ldots$ & $\ldots$ & 18.2 \\
\hline $60-70$ & " & ... & $\ldots$ & $\ldots$ & $\ldots$ & $\ldots$ & $\ldots$ & $\ldots$ & $\ldots$ & 9.0 \\
\hline
\end{tabular}

TABLE XVI.-Time of Occurrence of Dcath After Opcration.

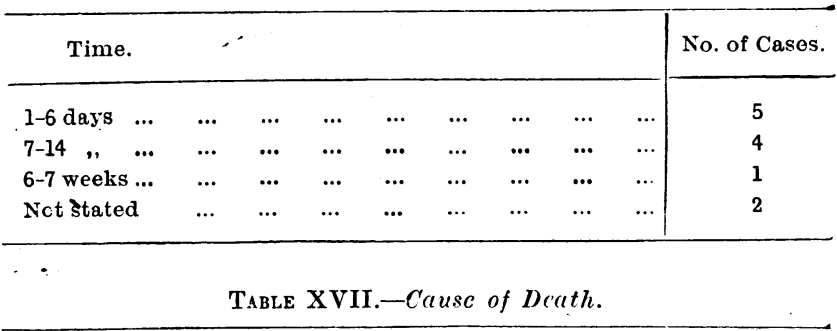

\begin{tabular}{|c|c|c|c|c|c|c|c|c|}
\hline \multicolumn{8}{|l|}{ Cause of Death. } & \multirow{2}{*}{$\frac{\text { No. of Cases. }}{2}$} \\
\hline Shock & $\ldots$ & $\ldots$ & $\cdots$ & $\ldots$ & $\ldots$ & $\ldots$ & $\ldots$ & \\
\hline Pneumonia & $\ldots$ & ... & ... & $\ldots$ & $\ldots$ & ... & $\ldots$ & 1 \\
\hline Subphrenic abscess & $\ldots$ & $\ldots$ & $\ldots$ & $\ldots$ & $\ldots$ & $\ldots$ &.. & 1 \\
\hline \multicolumn{4}{|c|}{ Erosion into transverse meso-colon } & $\ldots$ & $\ldots$ & $\ldots$ & $\ldots$ & 1 \\
\hline Cause not stated & ... & $\ldots$ & $\ldots$ & $\ldots$ & $\cdots$ & $\ldots$ & ... & 7 \\
\hline
\end{tabular}

Carcinoma developing at the Site of Ulcer.-No case was reported in the whole series.

Brief Summary of Results.

Perforated gastric ulcer was three times as common in males as in females.

Rather more than two-thirds of the perforations occurred between 30 and 50 years of age.

About 24 per cent. of the cases returned to full work within three months of the date of the operation. Abont 65 per cent. of the cases of perforated duodenal and pyloric ulcers returned to full work in the same period of time.

The results of the operations were satisfactory in about 77 per cent. of the cases that survived, as compared with the corresponding figure of about 89 per cent. for the perforated duodenal and pyloric ulcers.

The post-operative mortality was 28.6 per cent., as compared with the post-operative mortality of 13.6 per cent. among the perforated cluodenal and pyloric ulcers.

No case of carcinoma developing at the site of an ulcer was reported in the whole series. 